\title{
The Causal Relationship between Trade and Economic Growth in Sri Lanka
}

\author{
HERATH H.M.S.P. \\ Department of Banking and Finance, \\ Faculty of Business Studies and Finance \\ Wayamba University of Sri Lanka, \\ Kuliyapitiya, \\ SRI LANKA \\ E-mail: shan@wyb.ac.lk
}

\begin{abstract}
:-
International trade has become the engine of growth of world economies over the past few decades and main objective of this research is to investigate the causal relationship between trade liberalization and economic growth of Sri Lanka. The study is mainly based on secondary data collected from the Central Bank of Sri Lanka and in achieving the main objective data were collected on a specific time interval before and after the trade liberalization of the country. The study time period selected is from 1960 to 2012. To identify the impacts of trade liberalization, total time period is divided into two sub periods of before trade liberalization i.e. (from 1960 to 1976) and after trade liberalization i.e. (from 1977 to 2012). The variables identified in the main objective of the study are tested hypothetically, and regression analysis and chow test were employed to make accurate and reliable conclusion. The result of Chow test proves a clear change of economic growth before and after trade liberalization of Sri Lanka and the finding of the study confirms a significant positive relationship between trade liberalization and economic growth of the country.
\end{abstract}

Keywords:-Trade Liberalization, Economic Growth, trade policies

\section{Introduction}

Trade liberalization via the reduction or complete elimination of trade barriers has become the most popular economic policy of developed and developing countries today. Import and export tariffs, quotas, export subsidies, technical barriers are the key trade barriers which have been used during the last few decades. With globalization of world economies, all most all the counties in the world are being actively involved with reducing trade barriers among their trade partners. Major objective of moving towards free trade is to achieve macroeconomic goals of their economies. Basically developing countries are implementing free trade policies to achieve higher economic growth and reduce prevailing high unemployment rate. As a result trade openness has been widening up in these economies over the last few decades. In Sri Lanka trade liberalization process is being increasingly evolved with the expectation of rapid economic growth since 1977. Researchers have investigated to answer the question of how the trade liberalization is linked with economic growth of a country. However their studies have produced a mixed bag of results and these results have created the issue more complex in the world. Therefore this study attempts to find empirical evidences on the relationship 
between international trade and economic growth of Sri Lanka. Accordingly, the primary objective of the study is to investigate the relationship between trade liberalization and economic growth of Sri Lanka.

\section{Literature Review}

Attempts to measure relationship between trade liberalization and economic growth go back to decades. Until recently most studies which were carried out on finding relationship between these two variables depends on the comparison of gross domestic growth between closed and opened economies or before and after trade liberalization (Nash and Thomas,1991; Papageorgiou et al, 1991). These studies have identified a year of liberalization and after observing higher GDP growth rate after the reforms and concluded that trade liberalization leads to higher growth. However major limitation of this approach is that it doesn't control other factors that may affect to boost economic growth after trade liberalization.

In a major study of trade orientation, distortions and growth in developing countries, Edwards (1992) develops a model which assumes more open economies are more efficient at absorbing exogenously generated technology. Using various indicators of trade orientation constructed by Leamer (1988), the researcher shows for a sample of 30 developing countries over the period 1970-82 that more open economies tend to grow faster. In Economic Reform and Process of Global Integration, Sachs and Warner (1995) investigated trade and growth relationship of 79 countries over the period 1979-89. They apply the dummy variable technique and found that open economies grew on average by 2.44 percentage points faster than closed economies.
Aksoy and Salinas (2004) have carried out a study to investigate the relationship between economic growth before and after trade liberalization of world economies. The sample of the study constituted with 39 developing countries. In investigating the relationship between economic growth before and after trade liberalization of world economies Aksoy and Salinas (2004) have studied time series data from 1970 to 2004 for 34 countries and have identified that post reform economic growth of sample countries was 1.2 percent higher than before the reforms. Also study has found that trade liberalization has been followed by acceleration in investment, exports of goods and services, and manufacturing exports, and as opposed to common belief, outward orientation did not lead to significant deindustrialization and actually seems to have increased export diversification. Further study has identified that small countries have benefited more from the trade reforms.

To find out the trade liberalization and economic performance of countries the World Bank (WB) classified a group of 41 countries based on different degrees of outward and inward orientation in 1987. Four categories identified by the World Bank are Strongly outward oriented, Moderately outward oriented, Moderately inward oriented Strongly inward oriented countries. According to the World Bank study it concluded that economic performance of the outwardoriented economies has been broadly superior to that of inward-oriented economies in all respects. According to Balassa (1978), he has found a positive relation between an outward oriented regime and economic growth by observing countries that experience higher exports growth with a significantly higher economic growth even after removing exports from GDP accounting. However major point that could be kept in mind that exports growth 
can be flourished by GDP growth itself or some polices other than trade liberalization. Therefore this relationship may not reveal causality between trade liberalization and growth.

In Relationship between Trade Liberalization, Economic Growth and Trade Balance: An econometric investigation Parikh and Stirbu (2004) examined the relationship between liberalization and growth, liberalization and trade balance. Researchers have used panel data of 42 countries which are selected from Asia, Africa and Latin America. Findings suggest that trade liberalization promotes economic growth and further found that one unit change in liberalization index leads on average to 1.62 percentage point change in growth rates one average, ceteris paribus. Andersen and Babula (2008) have found a link between openness and long run economic growth of countries. They have reviewed the most cited empirical analyses of the relationship between international trade and economic growth and more empirical analyses of the link between trade and productivity growth. In their study they have concluded that there is likely to be a positive relationship between international trade and economic growth. However they have cited two caveats. First, they have concerned about the way problems of measurement error and endogeneity are handled in much of the empirical literature. The second caveat relates to the ability of developing countries to gain productivity growth through trade liberalization. To do so they have recommended investing in e.g., education facilities, to ensure property rights and to build up institutions.

However according to the study carried out by Sarkar (2005) it has found no meaningful relationship between the growth rate of real GDP or per capita real GDP and trade openness. The study has been based on two countries in Asian region, India and Korea. According to this study, in the first stage of simple trend analysis, it has been observed that both countries, India and Korea, opened up and consequently shares of trade in their GDPs rose significantly. The process of opening up of accelerated in India and decelerated in Korea after 1973. The study has identified that real growth rates of both India and Korea has been fluctuated and there has been some evidence of a rise in Indian real growth rates after post liberalization period. However the GDP and per capita GDP growth rate has been swelled in Korea at a rapid rate up to the beginning of the 1970s and fell subsequently. To identify the deterministic trend of variables Sarkar has employed two tests of stationarity called Augmented Dicky Fuller tests and perron tests. Those tests have exhibited that the series did not have deterministic trends so that temporary shocks could have permanent effects. Moreover the study has found no positive relationship between opening up and economic growth. Contrary to the expectations in the pro-liberalization circle, Sarkar has found a large negative relationship between trade openness and growth keeping calls for further investigation to explain such paradoxical finding.

\section{Methodology}

In identifying the association between trade liberalization and economic growth data is collected on a specific time interval before and after trade liberalization of Sri Lanka. The study is mainly based data published by the Central Bank of Sri Lanka (CBSL) and the time period selected for the study is from 1960 to 2013. Further to identify the impacts of trade liberalization, total time period is divided into two sub periods of before trade liberalization i.e. (1960 to 1976) and after trade liberalization i.e. (1977 to 2013). Since the study is based 
on time series data, price effects of variables are removed by using GDP deflator of respective years. The variables identified in the main objective of the study are tested hypothetically, and quantitative analytical methods are applied to make accurate and reliable conclusions. Descriptive statistics and regression analysis is mainly used to assess the degree of association between trade liberalization and economic growth. Structural changes of the economy are mainly identified by employing Chow test.

\section{Specifications of Simple Equations Model}

The study uses ordinary least square (OLS) method to derive regression models which are used to analyze the impacts of trade liberalization. The study uses simple regression model as far as possible to avoid the complexity. To examine the effects of trade liberalization on growth following equations are mainly used in the study.

$\mathrm{GR}=\mathrm{f}($ LIBER $)$

$\mathrm{GDP}=\mathrm{f}(\mathrm{t})$

Where, GR refers to economic growth, LIBER refers to trade liberalization, $t$ refers to time, GDP refers to gross domestic product.

\section{Measuring Growth Rate of a Variable}

The study uses linear log model in measuring growth rate of gross domestic product of Sri Lanka. Growth rate of a certain economic variable can be measured by applying simple regression analysis (Gujarati, 2004). Suppose that it is required to measure the growth rate of variable Y. According to the compound interest formula, it can be written down as in equation 1 .
$\mathrm{Y}_{\mathrm{t}}=\mathrm{Y}_{0}(1+\mathrm{r})^{\mathrm{t}}$

Where, $r$ is the compound (i.e. over time) rate of growth of variable Y. By taking natural logarithm of equation, it can be stated as in equation 2 .

$\ln \mathrm{Y}_{\mathrm{t}}=\ln \mathrm{Y}_{0}+\ln (1+\mathrm{r})$

\section{(2)}

Letting;

$$
\begin{aligned}
& \beta_{1}=\ln Y_{0} \\
& \beta_{2}=\ln (1+r)
\end{aligned}
$$

The equation 2 can be rewritten as,

$\ln \mathrm{Y}_{\mathrm{t}}=\beta_{1}+\beta_{2} \mathrm{t}$

By adding error term to equation 3, it can be re arranged the equation 3 and presented in equation 4.

$\ln Y_{\mathrm{t}}=\beta_{1}+\beta_{2} \mathrm{t}+\mathrm{u}_{\mathrm{t}}$

$-------(4)$

The model shown in equation 4 is similar to any other linear regression model and regression coefficients or parameters, $\beta_{1}$ and $\beta_{2}$ are considered as linear. The only difference of the regression model given in equation 4 is that dependent variable is in the form of logarithm of $\mathrm{Y}$ and the independent variable is "time". The independent variable that is time, takes values of $1,2,3,4 \ldots$ etc. In the formula shown in equation 4 , only one variable is appearing in the logarithm form and the model that is explained in equation 4 is called semi log model. In this particular model as only the independent variable is on logarithmic form it is called a log-lin model (Gujarati, 2004). The properties of log-lin model can be traced as follows.

In equation 3 , the slope coefficient measures the constant proportional or relative change in dependent variable $(\mathrm{Y})$ for a given absolute change in the value of the independent variable. In this study, 
lin - log model is applied to measure the growth rate of GDP and trade balance and time ( $t$ ) is taken as the independent variable. Therefore slope coefficient of model 3 can be written down descriptively as follows.

$\beta_{2}=\frac{\text { Relative Change in Dependent Variable }}{\text { Absolute Change in Independen Variable }}$ $-(5)$

In equation 5, if numerator is multiplied by 100 it will give the growth rate of dependent variable(Y) for an absolute change in independent variable $(\mathrm{X})$. The product of $\beta_{2}$ of the relevant model by 100 is known as the growth rate of the dependent variable.

\section{Results}

Impact of trade liberalization on economic growth is assessed by comparing economic condition prevailed before and after trade liberalization during the period from 1960 to 2013 in Sri Lanka. Descriptive statistics and graphical presentations are used to examine the behavioral pattern of key variables of the study. Descriptive analysis can give a useful insight about the relationship between economic growth and trade relationship. However, clear and accurate knowledge about the association of the variable concerned is tested by regression analysis and the Chow test is applied to examine the structural changes in economic growth of Sri Lanka.

\section{Descriptive Analysis}

Economic growth rates over the last few decades show quite irregular pattern due to internal and external shocks faced by the country. Table 1 summarizes the average economic growth rates for selected time periods. Economic growth rate shows an uneven pattern before
1977. Particularly during the $1970-1976$ period, Sri Lanka experienced the lowest economic growth and this period is known as the most trade restricted era ever had in Sri Lanka. For example economic growth rate of the country in 1971 was 0.2 percent and average growth was 2.68 percent during the $1971-1976$. After 1977 the country has been able to achieve more than 5 percent economic growth except during the 1986 - 1990 in which Sri Lanka was suffering from heavy civil unrest.

Table 1: Average Growth Rates for Sub Periods in Sri Lanka

\begin{tabular}{|c|c|}
\hline Period & $\begin{array}{c}\text { Average Growth } \\
\text { Rates }\end{array}$ \\
\hline $1960-1965$ & 4.15 \\
\hline $1966-1970$ & 5.24 \\
\hline $1971-1976$ & 2.68 \\
\hline $1977-1985$ & 5.61 \\
\hline $1986-1990$ & 3.40 \\
\hline $1991-2000$ & 5.20 \\
\hline $2001-2007$ & 5.06 \\
\hline $2008-2013$ & 6.56 \\
\hline
\end{tabular}

Source: Annual Reports of Central Bank of Sri Lanka

Literature provides several indicators to measure trade openness of a country. Figure 1 shows three measurements to quantify the trade openness of Sri Lanka. Total exports to gross domestic product(XGDP), imports to gross domestic product(MGDP) and total of exports and imports to gross domestic products(TGDP) shows behavior of trade openness of the country with changes of trade policies over the time. With trade liberalization these measurements are expected to increase. During the closed economic period from 1960 to 1977, all trade openness indicators shows falling trends and after 1977 with trade liberalization policies implemented in the country, all openness measurements were 
at their highest. It can be seen a clear difference of trade openness measurements of two trade regimes. After 1977 openness measures have been swinging with external and internal policies of the country. However, with compared to closed economic era, trade openness indicators show relatively high values after 1977.

Figure 1: Behavior of Trade Openness Measurements

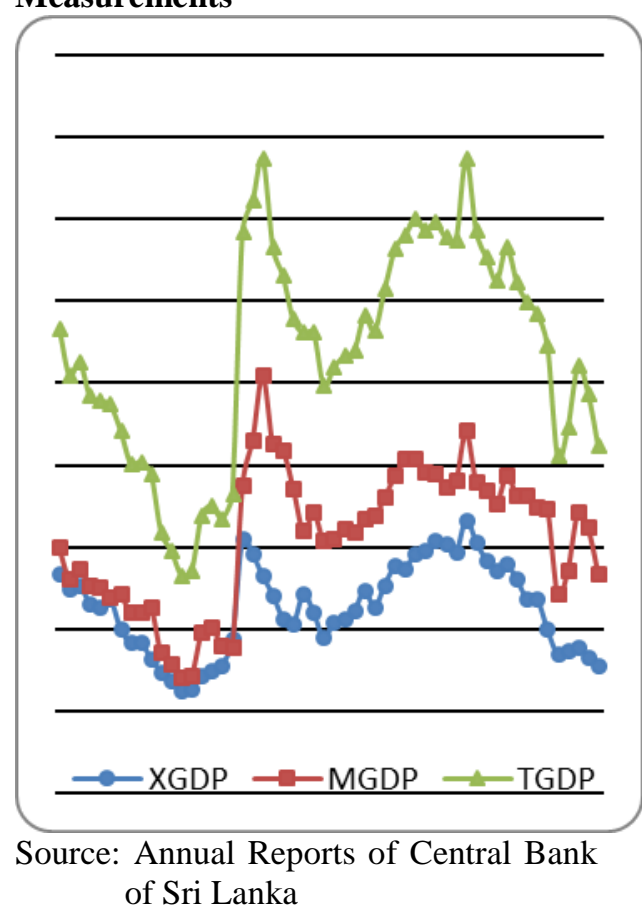

\section{Regression Results}

To measure the impact of trade liberalization on economic growth of Sri Lanka, mainly regression analysis is applied for the study time period. Firstly, to measure the impacts of trade liberalization on economic growth simple regression model is applied for two different policy regimes, before and after trade liberalization by employing trade liberalization dummy variable with GDP growth rate to examine impact of trade liberalization on growth. In the second stage, chow test is applied to examine whether there is any difference of average growth rates of two trade regimes.

\section{Table 2: Economic Growth (GR) versus Trade Liberalization (LIBER)}

\begin{tabular}{|l|l|l|l|}
\hline $\begin{array}{l}\text { Time } \\
\text { Period }\end{array}$ & R & Constant & Slope \\
\hline \multirow{3}{*}{$1960-$} & \multirow{2}{*}{0.672} & $\begin{array}{l}3.48 \\
(0.412)\end{array}$ & \\
\cline { 3 - 4 } & & & $\begin{array}{l}2.41 \\
(0.343)\end{array}$ \\
\hline
\end{tabular}

$\mathrm{DW}=1.93$

Note: Standard error is given in parentheses

Table 2 shows the causal relationship between economic growth and trade liberalization. Correlation coefficient of economic growth and trade liberalization is 0.672 and it shows a moderate positive relationship between two variables. Goodness of fit can be interpreted by using the value of coefficient of determinant $\left(\mathrm{R}^{2}\right)$ of this regression model and shows a moderate value which is equal to 0.45 . Individual regression parameters (intercept and slope) are significant at 1 percent level of significance (for intercept $\mathrm{p}$-value $<0.01$ and for slope coefficient $\mathrm{p}$-value $<0.01$ ). Also overall model is significant at 1 percent level of significance (p-value < 0.01). Durbin Watson (DW) statistic describes that the regression model is free from autocorrelation as its value is closer to 2. According to the regression results, the intercept of the regression model is 3.48 and slope coefficient is 2.41 . The intercept describes the average GDP growth of the country during closed economic period from 1960 - 1976 period. Average growth during the closed economic period is 3.48 percent. The slope coefficient of the model explains the impact of trade liberalization on economic growth and it shows that trade 
liberalization has accelerated the economic growth by 2.41 percent. Hence with trade liberalization, the economy has achieved on average 5.89 percent economic growth during the $1977-2012$ period.

Table 3: Gross Domestic Product versus Time

\begin{tabular}{|c|c|c|c|}
\hline $\begin{array}{c}\text { Time } \\
\text { Period }\end{array}$ & $\mathbf{R}$ & Constant & Slope \\
\hline $\mathbf{1 9 6 0 - 1 9 7 6}$ & 0.993 & $\begin{array}{c}11.9 \\
(0.012)\end{array}$ & $\begin{array}{c}0.0391 \\
(0.001)\end{array}$ \\
\hline $\mathbf{1 9 7 0 - 1 9 7 6}$ & 0.990 & $\begin{array}{c}12.3 \\
(0.008)\end{array}$ & $\begin{array}{c}0.0283 \\
(0.002)\end{array}$ \\
\hline $\mathbf{1 9 7 7 - 2 0 1 2}$ & 0.981 & $\begin{array}{c}11.6 \\
(0.017)\end{array}$ & $\begin{array}{c}0.051) \\
(0.001)\end{array}$ \\
\hline
\end{tabular}

Note: Standard errors are given in parentheses

The rate of growth of gross domestic product over pre and post liberalization period is estimated using log-linear regression model. To identify the growth rate effect of GDP in different policy regimes, total time period (1960-2007) is divided into two sub periods. One period is from 1960 to 1976 and the second period is from 1977 - 2012. Further to measure the growth rate of GDP in most restricted period in the country, another sub time period is taken from 1970 to 1976.

According to the table 3 , correlation coefficients $(\mathrm{R})$ for regression models are higher than 0.98 for all time periods. They show a strong positive relationship between GDP and time variable. Simple regression models derived for three different time periods depict higher coefficient of determination values. Coefficients of Determination $\left(\mathrm{R}^{2}\right)$ for regressions estimated for periods 196076, 1970-1976 and $1977-2012$ are
$0.99,0.98$ and 0.96 respectively. Therefore it is clear that more than 95 percent of total variation of GDP is explained by each regression model. Individual and overall significance of regression coefficients are fulfilled at 1 percent level of significance. Further Durbin Watson (DW) statistic describes that all three regression models are free from autocorrelation as their Durbin Watson statistics are closer to value of 2 . According to the each equation, slope coefficients of all three regressions describe GDP growth rates for three different time periods. Slope coefficients for three time periods, $1960-1976,1970$ -1976 and $1977-2007$ are $0.0391,0.0283$ and 0.051 respectively. During the period from 1960 to1976, GDP of the country has grown at a rate of 3.91 percent. However during the most restricted period starting from 1970 to 1976, growth rate of Gross Domestic Product has fallen to 2.83 percent. With trade liberalization in 1977 growth rate of Gross Domestic Product has climbed to 4.7 percent in Sri Lanka. As a whole it is proved that country has achieved higher economic growth after 1977 with trade liberalization.

\section{Hypothesis Testing for Structural Changes in Trade Liberalization and Economic Growth Relationship}

Chow test is applied to examine the structural changes in growth of Gross Domestic Product during the two trade policy regimes, closed economic era and open economic era. In applying Chow Test to examine whether there is any significant difference in economic growth rates of restricted economic era (from 1960 to 1976) and open economic era (from 1977 to 2007) total time period (from 1960 to 2007) is divided into two periods. Period one is considered as the closed economic period from 1960 to 1976 and period two is considered as liberalized economic period from 1977 to 
2007. By taking time as the independent variable and GDP as the dependent variable simple regression models are constructed for said periods. Finally in applying Chow test, simple regression technique is employed for total time period considered in the present research. In this study, GDP growth rates for three periods are computed by applying loglinear regression model and estimated regression results for three periods are shown in equation 6,7 and 8 .

\section{Period 1:}

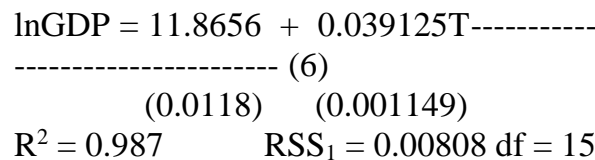

\section{Period 2:}

$\operatorname{lnGDP}=13.4127+0.058217 \mathrm{~T}-(7)$
$(0.0218) \quad(0.001023)$
$\mathrm{R}^{2}=0.964 \mathrm{RSS}_{2}=0.0743 \mathrm{df}=34$

\section{Period 3:}

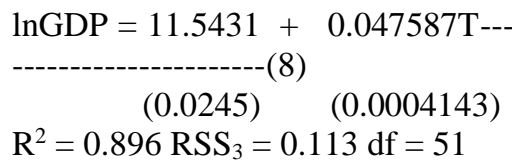

Two hypothesis built up to test structural changes are;

\section{Null Hypothesis $\left(\mathrm{H}_{0}\right)$ :}

Parameter Stability is there

\section{Alternative Hypothesis $\left(\mathrm{H}_{1}\right)$ : \\ Parameter Stability is not there}

The two hypotheses are tested by comparing Calculated $F$ value $\left(\mathrm{F}_{\mathrm{c}}\right)$ and $\mathrm{F}$ table value $\left(\mathrm{F}_{\mathrm{t}}\right)$. Decision rule to accept or reject null hypothesis is,

if $F_{c}<F_{t}$, null hypothesis is accepted and alternative hypothesis is rejected if $F_{c}>F_{t}$, null hypothesis is rejected and accepted alterative hypothesis.

$F_{c}$ statistic is calculated by using the formula given in equation 9 .

$$
F_{c}=\frac{\left[\left(R S S_{R}-R S S_{U R}\right) / K\right]}{R S S_{U R} /\left(n_{1}+n_{2}-2 k\right)} \ldots \ldots F_{\left[k,\left(n_{1}+n_{2}-2 k\right)\right]}
$$

Where

$\mathrm{RSS}_{\mathrm{R}}=$ Restricted residual sum of square $\mathrm{RSS}_{\mathrm{UR}}=$ Un-restricted residual sum of square

$\mathrm{K}=$ Number of parameters estimated

$\mathrm{n}_{1}=$ number of observations of period 1

$\mathrm{n}_{2}=$ number of observations of period 2

Based on simple regression models values for each term appeared in formula 9 are given below.

$\mathrm{K}=2, \quad \mathrm{n}_{1}=17, \quad \mathrm{n}_{2}=36$

$\mathrm{RSS}_{3}=\mathrm{RSS}_{\mathrm{R}}=0.113$

$\mathrm{RSS}_{1}+\mathrm{RSS}_{2}=\mathrm{RSS}_{\mathrm{U}}=0.00808+0.0743$

$=0.08238$

Based on the equation 9, calculated $\mathrm{F}$ value $\left(F_{c}\right)$ is 8.7433 and $F$ table value is equal to 3.15 at $5 \%$ level of significance. Accordingly null hypothesis is rejected by concluding that structural changes in GDP growth rate has been experienced during the sample period due to trade liberalization process undergone in the country.

\section{Conclusion}

The study encompassed five decades which belong to two trade regimes, pre and post liberalization process in Sri Lanka. The main objective of the study is to investigate the causal relationship between trade and economic growth of Sri Lanka. Accordingly the main hypotheses of the study was to test the relationship between trade liberalization and the Sri Lanka's economic growth during the pre and post liberalization era. 
Findings confirm a positive significant relationship between trade liberalization and economic growth of the country. The result of Chow test proves a clear change of economic growth before and after trade liberalization of the country. The study shows that liberalization has increased the economic growth of the country by 2.41 percent. During the closed economic period the economic growth has been 3.48 percent and this average economic growth further has been improved by trade liberalization. As a result Sri Lanka has achieved a 5.89 percent average economic growth after trade liberalization of the country. This resulted to increase the average economic growth rate by 2.41 percent with trade liberalization. Further to assess the robustness of the result, three simple regressions were regressed against time for two trade regimes. The results of simple regressions showed higher growth rate during liberalized trade regime with compared to the economic growth in the most restricted period of the country. The country has achieved 2.83 percent economic growth during the $1970-1976$ period. It climbed up to 5.1 percent during the 1977- 2012 period. This result further showed that international trade has improved economic growth by 2.27 percent.

\section{Reference}

Adhikari, C., \& Weiss, J. (Eds.). Industrial and trade policy reform in developing countries, Manchester: Manchester University Press.

Agosin, M. (1991). Trade policy reform and economic performance: A review of the issues and some preliminary evidence. UNCTAD Discussion Papers No.41, UNCTAD, Geneva.
Ahmed, N. (2000). Export responses to trade liberalization in Bangladesh: A co integration analysis, Applied Economics, Vol. 32.

Aksoy A. and Salinas G. (2004), Growth before and after Trade Liberalization, World Bank Policy Research Working Paper, World Bank.

Balassa, B. (1978). Exports and economic growth: Further evidence. Journal of Development Economics, Volume 5.

Bhagwati, J.N. (1978). Anatomy and consequences of exchange control regimes. Cambridge, Massachusetts: Ballinger Pub.Co.

Bleaney, M. (1999), Trade reform, macroeconomic performance and export growth in ten Latin American countries 1979-95. Journal of International Trade and Economic Development, Vol.8, No.1.

Blecker, R.A. (1998). International competitiveness, relative wages, and the balance of payments constraint. Journal of Post Keynesian Economics.

Clarke, R. \& Kirkpatrick, C. (1992), Trade policy reform and economic performance in developing countries: Assessing the empirical evidence

Dollar, D. (1992). Outward-oriented developing countries really do grow more rapidly: Evidence from 95 LDC's, 1976-85. In Economic Development and Cultural Change 40(April).

Edwards, S. (1992), Trade orientation, distortions and growth in 
developing countries. Journal of Development Economics, July.

Edwards, S. (1993), Openness, trade liberalization, and growth in developing countries. Journal of Economic Literature, (September).

Edwards, S. (1998). Openness, Productivity and Growth: What Do We Really Know? Economic Journal 108(447).

Feder, G. (1983). On exports and economic growth. Journal of Development Economics, February/April.

Frankel, J.A., (2000). Assessing the efficiency gains from further liberalization. KSG Faculty Research Working paper No RWP01-030.

Greenaway, D. \& Sapsford D. (1994), What does liberalization do for exports and growth?. Weltwirtschaftliches Archiv, Vol. 130.

Greenaway, D. Morgan, W. \& Wright, P. (2002). Trade liberalization and growth in developing countries. Journal of Development Economics, Vol. 67.

Harberger, A. (1950). Currency depreciation, income and the balance of trade. Journal of Political Economy.

Joshi, V. \& Little, I.M.D. (1996). India's economic reforms 1991-2001. Oxford: Oxford University Press.

Kelegama, S. (2004). Economic policy in Sri Lanka: Issues and debates. ( $1^{\text {st }}$ ed.). Colombo.
Khan, M.S. \& Zahler, R. (1985). Trade and financial liberalization given external shocks and inconsistent domestic policies, IMF Staff Papers, vol. 32 (March).

Lakshman, W.D. (1997). Dilemmas of development, Sri Lanka Association of Economists, Colombo

Leamer, E. (1988). Measures of Openness, Chicago: Chicago University Press

Li, K., Morck, R., Yank, F. \& Yeung, B. (2004). Firm-Specific Variation and Openness in Emerging Markets, The Review of Economics and Statistics 86.

Little, I., Scitovsky T. and Scott, M. (1970), Industry and Trade in Some Developing Countries: A Comparative Study, Cambridge: Oxford University Press.

Ostry, J. \& Rose, A. (1992). An empirical evaluation of the macroeconomic effects of tariffs, Journal of International Money and Finance, vol. 11 (February).

Papageorgiou, D. Michaely, M. \& Choksi, A. (1991). Liberalizing Foreign Trade ,Oxford: Basil Blackwell

Salinas, G. and Aksoy, A. (2004), Growth before and after trade liberalization, World Bank Policy Research Working Paper 4062, World Bank

Salvatore, D. (2005), International Economics, Prentice-Hall, India

Todaro, M. P. (1994). Economic Development, $5^{\text {th }}$ Edition, Longman Group Limited, Burnt 
Mill, Harlow, Essex CM20 2JE, England.

Todaro, Michel P., \& Smith, Stephen C. (2004). Economic Development$8^{\text {th }}$ Edition, Pearson Education (Pvt.) Ltd., Delhi 110 092, India.

UN Millennium Project, Task Force on Trade. 2005. Trade for development.New York: United Nations, Available from: http://www.ycsg.yale.edu.

UNCTAD (1999), Trade and Development Report 1999, GenevaWacziarg, R. (2001), "Measuring the dynamic gains from trade", World Bank Economic Review, Vol. 15 (3).

World Bank (1993), The East Asia Miracle: Economic growth and public policies. Washington, D.C.: World Bank.

Parikh, A. and Stirbu C. (2004). Relationship between Trade Liberalization, Economic Growth and Trade Balance: An econometric investigation. HWWA Discussion Paper, Hamburgisches Welt-WirtschaftsArchiv (HWWA) Hamburg Institute of International Economics.

Sachs, J. D. and A. Warner (1995). "Economic Reform and the Process of Global Integration." Brookings Papers on Economic Activity 1995(1): 1-118. 